\title{
DETERMINATION OF LEAD AND OTHER ELEMENTS IN GOLD MATRIX USING PROTON INDUCED X-RAY EMISSION AT MAGA, DANKO WASAGU, KEBBI, NIGERIA
}

\author{
Daniel D. ${ }^{1}$, Bello A. ${ }^{2}$, Abdurrahman A. ${ }^{3}$ and Jonathan I.K. ${ }^{2}$ \\ ${ }^{1}$ Department of Physics, Kebbi State Government Girls Science College Riba. Email: \\ danny44phy@gmail.com \\ ${ }^{2}$ Department of Physics, Kebbi State University of Science and Technology Aliero \\ P.M.B.1144. Email: bello.abdullahi455@gmail.com \& komojonathan@gmail.com \\ ${ }^{3}$ Department of General Studies, Kebbi State College of Nursing Science Brining Kebbi \\ P.M.B 1133. Email: alkangiwee@yahoo.com
}

Cite this article:

Daniel D., Bello A., Abdurrahman A., Jonathan I.K. (2021), Determination of Lead and Other Elements in Gold Matrix Using Proton Induced X-Ray Emission At Maga, Danko Wasagu, Kebbi, Nigeria. African Journal of Environment and Natural Science Research 4(4), 11-15. DOI: 10.52589/AJENSRJKQDUZFM.

\section{Manuscript History}

Received: 11 July 2021

Accepted: 3 July 2021

Published: 17 Aug 2021

Copyright $\odot 2020$ The Author(s). This is an Open Access article distributed under the terms of Creative Commons AttributionNonCommercial-NoDerivatives 4.0 International (CC BY-NC-ND 4.0), which permits anyone to share, use, reproduce and redistribute in any medium, provided the original author and source are credited.
ABSTRACT: Lead poisoning is becoming an epidemic in and around Kebbi State lately. Five samples were collected from mining Sites believed to have high lead concentration. Proton induced X-ray emission (PIXE) technique of $2.5 \mathrm{MeV}$ proton beam was used to characterize five geological samples collected from Maga, Danko Wasagu LG, Kebbi State, Nigeria to determined concentration of Lead $(\mathrm{Pb})$ and other trace elements. Samples were irradiated and analyzed at Centre for Energy Research and Development, Ile-Ife, Osun State, Nigeria. The result obtained indicated that $P b$ is of commercial deposit in all the samples. Alongside, $\mathrm{Si}, \mathrm{S}, \mathrm{K}, \mathrm{Ca}, \mathrm{Ti}, \mathrm{Cr}, \mathrm{Fe}, \mathrm{Cu}, \mathrm{Zn}$, $\mathrm{Rb}, \mathrm{Sr}, \mathrm{Zr}, \mathrm{Ba}, \mathrm{P}, \mathrm{V}, \mathrm{Mn}, \mathrm{Cl}, \mathrm{Ce}$ and $\mathrm{Ni}$ were determined. The result obtained for $\mathrm{Pb}$ concentration in samples $A, B, C, D$ and $E$ were 943ppm, 445ppm, 3279ppm, 2120ppmand 529ppm respectively, which is above the world health recommendation of 400ppm for areas with children.Also element $\mathrm{Si}$ and $\mathrm{Fe}$ concentrations appear to be deposited in commercial quantities. These values imply that the miners and surrounding communities of Maga, Danko Wasagu LG, Kebbi State, Nigeria are at risk of learning disabilities, attention deficit disorders, behavioural problems, stunted growth, hearing problems, anaemia, kidney damage, stomach pain, mental retardation, coma, and death due to the high concentration of $\mathrm{Pb}$.

KEYWORDS: Proton Induced X-ray Emission (PIXE), Lead $(\mathrm{Pb})$, Centre for Energy Research Development (CERD). 


\section{INTRODUCTION}

Mining is the process of obtaining useful minerals from the earth's crust. This process includes excavations and removal of rock and earth. Any excavation in the earth from which ore, coal, or other minerals are extracted is called a mine (Encarta, 2005). Gold matrix consists of several element; some are harmless while others are harmful. Of the harmful elements, include Lead $(\mathrm{Pb})$ and Arsenic (As) and the harmless elements include zinc $(\mathrm{Zn})$ and silicon $(\mathrm{Si}) . \mathrm{Pb}$ is found to be harmful especially to children if they are exposed over a period of time. Children under the age of six, especially unborn babies are most susceptible to lead poisoning because their brains and central nervous systems are still developing. Childhood lead poisoning causes reduced intelligent quotient (IQ), learning disabilities, attention deficit disorders, behavioural problems, stunted growth, hearing problems, anaemia, kidney damage, and stomach pain. High levels can cause mental retardation, coma, and death. Exposed adults may suffer high blood pressure, fertility problems, nerve disorders, muscle and joint pain, irritability, and memory or concentration problems. Most adults with lead poisoning are exposed through occupations such as house painting, welding, renovation and remodelling activities, smelters, firing ranges, the manufacture and disposal of car batteries, and the maintenance and repair of bridges and water towers (Fewtrell, 2003).

PIXE is an acronym that stands for Particle or Proton Induced X-rays Emission is one of the primary methods of analyzing $\mathrm{Pb}$ in the environment samples. PIXE is non-destructive. Therefore, the samples is not destroyed or consumed in the analysis. PIXE consists of two parts. The first is to identify the atomic species in the target from the energies of the characteristic peaks in the X-ray emission spectrum and the second part is to determine the amount of a particular element present in the target from the intensity of its characteristic Xray emission spectrum.

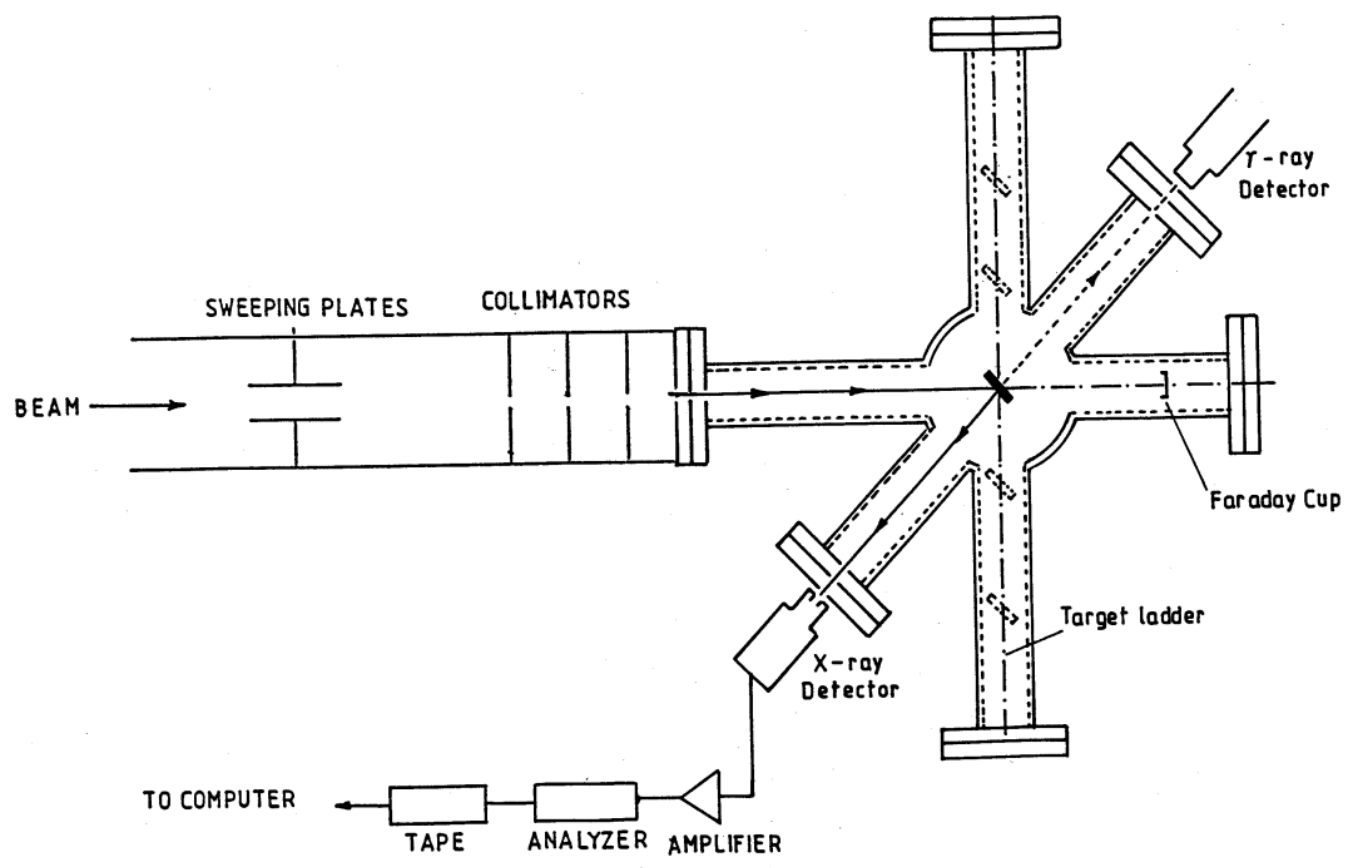

Figure1. Schematic diagram showing the basic experimental arrangement and target chamber of a PIXE set-up (Govil, 2001). 


\section{METHODOLOGY}

\section{Study Area}

The study area of this research work is a mining area in Maga. Maga is a village under Danko-wasagu Local Government, which lied within the latitude $6^{\circ} \mathrm{E}$ and longitude $11^{\circ} \mathrm{N}$, Zuru Emirate, kebbi State, Nigeria (Hassan, 2013).

\section{Materials}

The total of five samples was collected at places where gold mining were been undertaken. Samples were collected by picking with hand from the place of gold mining across Maga, Danko-wasagu LG, Kebbi State, Nigeria.

\section{Sample Preparation and irradiation}

The samples collected were taken to Centre for Energy Research and Development (CERD), Obafemi Awolowo University, Ile-Ife, Osun State, Nigeria. Each sample was crushed and grinded into powdered form and then labelled separately to avoid contamination (Buhari, 2018 B). This was successfully carried out at the geology department of the institution, after thorough mixing of the powdered materials with some binding agent such as chemflex TM, pellets are prepared with a hydraulic press. Five pellets are made and thereafter fastened to the specimen holder (special ladder akin to a slide projector, which enables the analysis of many (100) in sequence) (Abdullahi, 2012). The aluminium foil paper is placed behind the pellets before it is fastened to the special ladder to avoid the masking tape sticking to the pellets. It is then meticulously lowered in to the specimen chamber. Once the specimen is securely placed in the specimen chamber, the chamber is made vacuous by a special vacuum pump affixed to the chamber. Now ready for irradiation (Buhari, $2018 \mathrm{~A}$ ).

The samples were irradiated using $2.5 \mathrm{MeV}$ tandefm accelerator at the Centre for Energy Research and Development (CERD), Obafemi Awolowo University (OAU) Ile-Ife, Osun State, Nigeria. The target was placed at an angle of $45^{\circ}$ with respect tothe proton beam from the accelerator (Arifet al, 2016). Each sample is irradiated and counted (for $10 \mathrm{~min}$ ). Subsequently, the spectrum obtain is stored for qualitative and quantitative calculation at a later date. Irradiation is done together with Standard Reference Material (SRM) for relative quantitative calculation and quality control. The precision and trueness of the method were checked by analyzing the two SRMs under the same experimental condition as the samples. 


\section{RESULTS AND DISCUSSION}

Table 3.1 Average Concentration (ppm) of Elements in the Samples

\begin{tabular}{|c|c|c|c|c|c|}
\hline Analyte & Sample A & Sample B & Sample C & Sample D & Sample E \\
\hline $\mathrm{Pb}$ & 943 & 445 & 3279 & 2120 & 529 \\
\hline $\mathrm{Si}$ & 401635 & 444312 & 373673 & 437781 & 443747 \\
\hline $\mathrm{S}$ & 5513 & 1135 & 4333 & 6319 & 451 \\
\hline $\mathrm{K}$ & 20605 & 7808 & 21195 & 10366 & 9133 \\
\hline $\mathrm{Ca}$ & 249 & 522 & 376 & 1439 & 268 \\
\hline $\mathrm{Ti}$ & 703 & 333 & 2148 & 1518 & 644 \\
\hline $\mathrm{Cr}$ & 752 & 550 & 736 & 614 & 605 \\
\hline $\mathrm{Fe}$ & 18569 & 19161 & 33595 & 18804 & 15149 \\
\hline $\mathrm{Cu}$ & 2452 & 98 & 272 & 402 & 35 \\
\hline $\mathrm{Zn}$ & 33 & 25 & 30 & 36 & BDL \\
\hline $\mathrm{Rb}$ & 53 & 50 & 83 & 33 & BDL \\
\hline $\mathrm{Sr}$ & 57 & 63 & 128 & 81 & BDL \\
\hline $\mathrm{Zr}$ & 139 & 76 & 176 & 240 & 149 \\
\hline $\mathrm{Ba}$ & 608 & 382 & 625 & BDL & 409 \\
\hline $\mathrm{P}$ & $\mathrm{BDL}$ & 880 & BDL & BDL & BDL \\
\hline $\mathrm{V}$ & BDL & 36 & BDL & 48 & BDL \\
\hline $\mathrm{Mn}$ & BDL & 96 & BDL & 146 & 67 \\
\hline $\mathrm{Cl}$ & BDL & BDL & 117 & 92 & BDL \\
\hline $\mathrm{Ce}$ & BDL & BDL & BDL & 100 & BDL \\
\hline $\mathrm{Ni}$ & BDL & BDL & BDL & BDL & 8 \\
\hline & & & & & \\
\hline
\end{tabular}

Table 3.1 shows the average concentration (ppm) of elements in sample A, B, C, D, and E the table contain 20 elements, element concentration and oxide concentration. It was observed that silicon $(\mathrm{Si})$ has the highest element concentration in sample $\mathrm{A}, \mathrm{B}, \mathrm{C}, \mathrm{D}$ and $\mathrm{E}$ to be 401635ppm, 444312ppm, 373673ppm, 437781ppm and 443747ppm. Element Nickel (Ni) has the lowest element concentration of 8ppm and detected only in sample E, in sample A, B, $\mathrm{C}$ and $\mathrm{D}$ are below detection limit. The table shows the level of element lead concentration in sample A, B, C, D and E to be 943ppm, 445ppm, 3279ppm, 2120ppm and 529ppm, which is above the world health recommendation of 400ppmfor areas with children.

The samples in the study area indicated high deposit of $\mathrm{Fe}$ and $\mathrm{K}$, but $\mathrm{Fe}$ seem to be more promising. All the samples have a deposit of $\mathrm{Fe}$ at a very high concentration; most at above the normal (Buhari \& Bello, 2019). Since Nigeria is making frantic effort in resuscitating its iron industries located at Ajaokuta (Nigeria), it would be prudent if this area is further subjected to comparative analytical scrutiny. $\mathrm{Pb}$ concentration in most of the gold ores in this research work was observed to be several hundred times above the normal $\mathrm{Pb}$. 


\section{CONCLUSION}

PIXE technique was observed to be good at analyzing trace level of lead in gold ores because of the low detection limit. Lead concentrations were usually high in all the samples. The concentration values are far above the average reported values associated with gold ores. In a particular sample, lead concentration was found to be 564times above the world health recommendation of $400 \mathrm{ppm}$. We infer that this is the evidence of the widespread lead poisoning occurrences in and around surrounding communities of Maga, DankoWasagu, Kebbi State, Nigeria.

\section{REFERENCE}

Abdullahi B (2012) "The Determination of Zirconium from North-Western Nigeria using PIXE Technique" InternationalJournal of Science and Technology, Volume 2 No.9, PP (613-617).

Arif R, Mohsin R, Nisar A, Athar N, Shahzad S, and ShahnawazM (2016) "Determination of trace elements in tap water usingpixe technique" Journal of Chemical and Pharmaceutical Sciences, Volume 9 Issue 1, PP (34 -38).

Buhari S and Bello A, (2019). Determination of Potassium and Silicon from Left-Over of Gold Ore using Proton Induced X-ray Emission. Fudma Journal of Science (FJS). Vol.3, No.1.

Buhari S, (2018).Determination of Lead from Tailings of Gold Matrix using Proton Induced $X$-ray Emission International Journal of Science and Research (IJSR) Vol. 8, Issue 1, pp110-112. (Buhari, 2018 B)

Buhari S, (2018).Trace Element Analysis by PIXE in Tailings of Gold Ore Samples of Maga Mining Area of Danko-Wasagu. International Journal of Interdisciplinary Research and Innovations ISSN 2348-1226 (online) Vol. 6, Issue 3, pp594-597, Available at: www.researchpublish.com (Buhari, 2018 A)

Encarta, (2005). Mine Safety. Encarta Encyclopedia. Microsoft Encarta Premium, 2005.

Fewtrell L, Kaufmann R, Prüss-Üstün A, (2003). Lead: Assessing the environmental burden of diseaseat national and local levels. Geneva, World Health Organization Environmental BurdeDisease Series, No. http://www.who.int/quantifying_ehimpacts/publications/en/leadebd2.pdf).

Govil I. M, (2001). Department of Physics, Panjab University, Chandigarh 160014, India. Current Science, Vol.80, No.12. pp1-8, June.

Hassan B (2013) "Upgrading of wasagu (kebbi state) manganese ore to metallurgical grade concentrate" a thesis submitted to the school of post graduate studies, Ahmadu Bello University Zaria. 